[Denpun Kagaku, Vol.40, No. 3, p. 311 314 (1993)]

Note

\title{
Conversion of Sucrose into Laminaribiose Using Sucrose Phosphorylase, Xylose Isomerase and Laminaribiose Phosphorylase
}

\author{
Motomitsu KITAOKA,* Takashi SASAKI** and Hajime TANIGUCHI**,*** \\ * Nippon Petrochemicals Co., Ltd. \\ (1-3-1, Uchisaiwaicho, Chiyoda-ku, Tokyo 100, Japan) \\ ** National Food Research Institute \\ (2-1-2, Kannondai, Tsukuba 305, Japan) \\ *** Irvate Prefecture Brewing and Food Research Institute \\ (26, Tsushida, Morioka 020, Japan)
}

\begin{abstract}
Laminaribiose was synthesized from sucrose by coupling reactions of sucrose phosphorylase, xylose isomerase and laminaribiose phosphorylase in the presence of a catalytic amount of $P_{i}$. For the synthesis, a reaction mixture $(2 \mathrm{ml})$ containing $200 \mathrm{mM}$ sucrose, $20 \mathrm{mM} \mathrm{P}_{i}, 0.47 \mathrm{U} / \mathrm{ml}$ sucrose phosphorylase, $0.072 \mathrm{U} / \mathrm{ml}$ xylose isomerase, and $0.37 \mathrm{U} / \mathrm{ml}$ laminaribiose phosphorylase in $50 \mathrm{mM}$ imidazole- $\mathrm{HCl}$ buffer ( $\mathrm{pH} \mathrm{7.0)}$ was used. The concentration of laminaribiose reached $110 \mathrm{mM}$ after $48 \mathrm{hr}$ incubation at $37^{\circ} \mathrm{C}$. Laminaritriose was also formed in the same mixture after $15 \mathrm{hr}$, and its concentration reached $22 \mathrm{mM}$.
\end{abstract}

Laminaribiose is $\beta$-1,3-linked glucobiose. This compound has been expected as one of new food or industrial materials, such as a soluble dietary fiber or a growth-promoting factor of bifidobacteria (unpublished results). It can be produced by partial hydrolysis or acetolysis of $\beta$-1,3-glucan with enzymes or acids. $^{1-4)}$ However, it is very difficult to produce industrially laminaribiose by these methods because $\beta$-1, 3-glucan is not inexpensive. Laminaribiose also can be synthesized from glucose1-phosphate (G-1-P) and glucose using a crude extract of Euglena gracilis $Z$ cells containing laminaribiose phosphorylase [EC 2.4.1.31] and $\beta$-1, 3-oligoglucan phosphorylase [EC 2.4.1.30], ${ }^{\text {) }}$ but G-1-P is not also inexpensive. Furthermore, the yield of laminaribiose is not high, because of forming higher laminarioligosaccharides catalyzed by the latter enzyme. We developed a novel method to synthesize cellobiose from sucrose using sucrose phosphorylase, xylose isomerase and cellobiose phosphorylase. ${ }^{6)}$ The method can be applied for synthesis of laminaribiose. The present paper describes the new method for synthesis of laminaribiose.

Sucrose phosphorylase from Leuconostoc mesenteroides [EC 2.4.1.8] was purchased from Sigma Chemical Co. (St. Louis, USA). Xylose isomerase (glucose isomerase, [EC 5. 3. 1.5] from Streptomyces was purchased from Kanto Chemicals (Tokyo, Japan) as dried cells and extracted by sonication. ${ }^{6}$ ) Laminaribiose phosphorylase was purified from a crude extract of $E$.gracilis Z (IAM E-6) cells by using hydrophobic chromatography to be separated from $\beta$-1,3-oligoglucan phosporylase. ${ }^{7)}$

One unit of sucrose phosphorylase was defined as the amount of the enzyme which produced $1 \mu \mathrm{mol} \mathrm{G}-1-\mathrm{P}$ per minute from $10 \mathrm{mM}$ sucrose and $10 \mathrm{mM} \mathrm{P}_{i}$ in $50 \mathrm{mM}$ imidazole- $\mathrm{HCl}$ buffer $(\mathrm{pH} 7.0)$ at $37^{\circ} \mathrm{C}$. That of laminaribiose phosphorylase was defined as the amount of the enzyme which produced $1 \mu \mathrm{mol} \mathrm{P}_{i}$ from $10 \mathrm{mM}$ glucose and $10 \mathrm{mM} \mathrm{G}-1-\mathrm{P}$ in the same 
condition. That of xylose isomerase was defined as the amount of the enzyme which produced $1 \mu \mathrm{mol}$ glucose from $10 \mathrm{~mm}$ fructose in the same condition. The amount of G-1-P was measured by the phosphoglucomutase-glucose6-phosphate dehydrogenase system. ${ }^{8)}$ That of glucose was done by the glucose oxidaseperoxidase system with mutarotase using Glucose C Test Wako (Wako Pure Chemicals, Osaka, Japan).9) Those of oligosaccharides were measured by HPLC equipped with an RI detector using LiChrosorb $\mathrm{NH}_{2}$ column (Cica-Merck, Tokyo, Japan) with $80 \%$ acetonitrile as a solvent. The products which formed in the reaction were identified by comparing their retention times on HPLC using both LiChrosorb $\mathrm{NH}_{2}$ column (solvent : $80 \%$ acetonitrile) and LiChrosorb RP18 column (Cica-Merck, solvent : distilled water) with those of the standard laminarioligosaccharides (Yaizu Suisankagaku, Yaizu, Japan).

The new method to synthesize laminaribiose consists of three enzymatic reactions as following reaction formulae.

Sucrose $+\mathrm{P}_{i} \rightleftharpoons \mathrm{G}-1-\mathrm{P}+$ Fructose

Fructose $\rightleftharpoons$ Glucose

$\mathrm{G}-1-\mathrm{P}+$ Glucose $\rightleftharpoons$ Laminaribiose $+\mathrm{P}_{i}$

Sucrose $\rightleftharpoons$ Laminaribiose

At first, sucrose is phosphorolyzed into fructose and G-1-P by sucrose phosphorylase as in Formula (1). The resultant fructose is converted to glucose by xylose isomerase as in Formula (2). Then glucose and G-1-P are condensed into laminaribiose with release of $\mathrm{P}_{i}$ by laminaribiose phosphorylase as in Formula (3). When the reaction formulae are summed up, Formula (4) is obtained indicating that sucrose can be converted into laminaribiose in a single reaction mixture containing the three enzymes and a catalytic amount of $\mathrm{P}_{i}$. In the case of the enzymatic synthesis of cellobiose, ${ }^{6)}$ laminaribiose phosphorylase using in Formula (3) is substituted with cellobiose phosphorylase.

The reaction was carried out in $2 \mathrm{ml}$ of 50 $\mathrm{mM}$ imidazole- $\mathrm{HCl}$ buffer ( $\mathrm{pH}$ 7.0) containing the following compositions : $200 \mathrm{mM}$ sucrose, $20 \mathrm{mM} \mathrm{P}_{i}, 0.47 \mathrm{U} / \mathrm{ml}$ sucrose phosphorylase, $0.072 \mathrm{U} / \mathrm{ml}$ xylose isomerase, $0.37 \mathrm{U} / \mathrm{ml} \mathrm{lami-}$ naribiose phosphorylase and $5 \mathrm{mM} \mathrm{MgCl}$. The

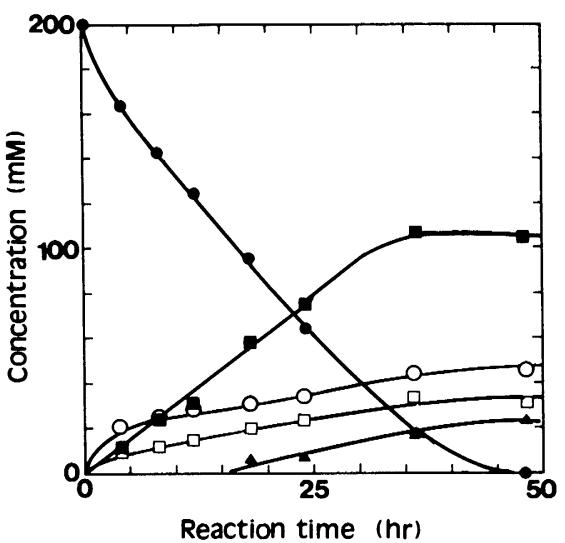

Fig. 1. Time profile of the reaction.

$\bullet$, sucrose ; $\boldsymbol{\square}$, laminaribiose ; $\mathbf{\Lambda}$, laminaritriose ; $\bigcirc$, fructose ; $\square$, glucose.

result is shown in Fig. 1. Sucrose decreased during the reaction and disappeared after 48 $\mathrm{hr}$. On the other hand, laminaribiose increased with decrease in sucrose, but not stoichiometrically. Its concentration reached $110 \mathrm{mM}$ after $48 \mathrm{hr}$. Laminaritriose appeared after $18 \mathrm{hr}$ and finally reached $22 \mathrm{mM}$. Concentrations of fructose and glucose increased during the reaction to become $46 \mathrm{mM}$ and $31 \mathrm{mM}$, respectively, after $48 \mathrm{hr}$. At the final state of the reaction, a trace amount of laminaritetraose was detected on the chromatogram.

The retention times of the laminaribiose synthesized in the reaction on the two different columns corresponded to those of the standard laminaribiose. To confirm its structure, the laminaribiose $(25 \mathrm{mg}$ ) was isolated from $1 \mathrm{ml}$ of the reaction mixture using a column of Toyopearl HW40S (Tohsoh, Tokyo, Japan, 2.5 $\mathrm{cm} \times 40 \mathrm{~cm}$ ) after treating the mixture with invertase, and its ${ }^{13} \mathrm{C}-\mathrm{NMR}$ spectrum was taken in $\mathrm{D}_{2} \mathrm{O}$ using a JNM-GX400 spectrometer (JEOL, Tokyo, Japan) as shown Fig. 2. The spectrum obtained supports that the structure is $\beta-1,3$ linked glucobiose, and it corresponds to that of a standard laminaribiose.

In the case of the cellobiose synthesis, ${ }^{6)}$ cellobiose increased stoichiometrically with decrease in sucrose, and no cellotriose or higher oligosaccharides appeared in the reaction mixture. The cellobiose phosphorylase cannot use cellobiose as a glucosyl acceptor. ${ }^{10}$ ) 


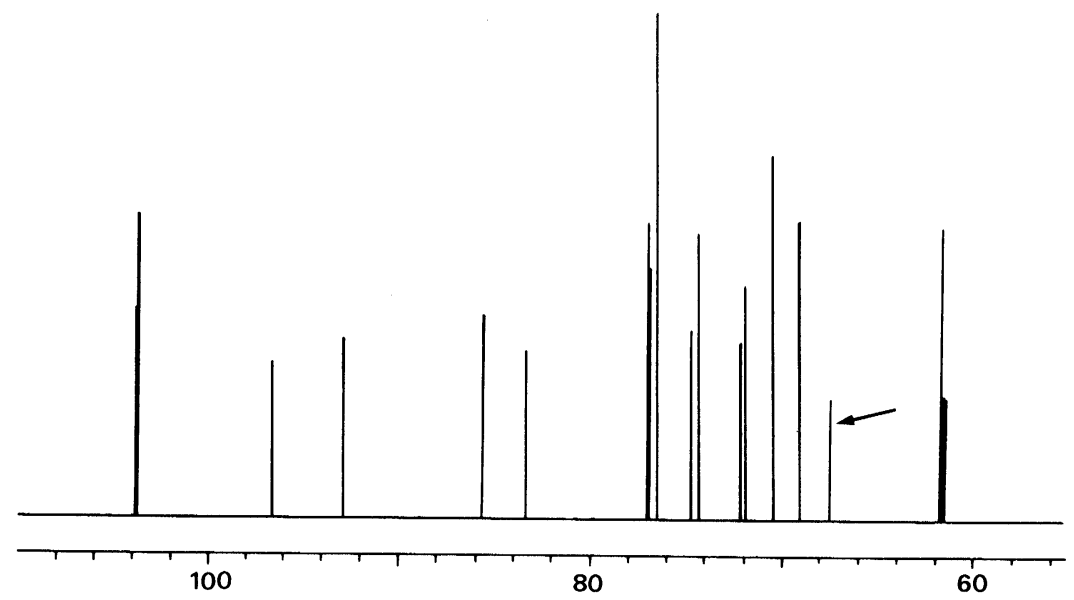

Fig. 2. A ${ }^{13} \mathrm{C}-\mathrm{NMR}$ spectrum on the laminaribiose synthesized.

Values were indicated in $\delta$ ppm. Dioxane was used as an internal standard (67. $4 \mathrm{ppm}$, indicated by an arrow).

However, the laminaribiose phosphorylase can use laminaribiose as a glucosyl acceptor to form laminaritriose with a lower rate compared with glucose. ${ }^{7,11}$ Formation of laminaritriose (and laminaritetraose) is probably due to the following by-reaction.

$$
\begin{gathered}
\text { laminaribiose }+\mathrm{G}-1-\mathrm{P} \rightleftharpoons \\
\text { laminaritriose }+\mathrm{P}_{i} \\
\begin{array}{c}
\text { (laminaritriose }+\mathrm{G}-1-\mathrm{P} \rightleftharpoons \\
\text { laminaritetraose } \left.+\mathrm{P}_{i}\right)
\end{array}
\end{gathered}
$$

Laminaribiose was synthesized at $55 \%$ yield from sucrose. This result suggests that laminaribiose can be produced effectively from inexpensive materials. Xylose isomerase is produced industrially and is commercially available. Recently, cloning and overexpression of sucrose phosphorylase were reported. ${ }^{12}$ ) However, laminaribiose phosphorylase is not commercially available so far. If commercial production of this enzyme is realized, the present method can be used for industrial production of laminaribiose.

In addition, 1 mole of laminaritriose was formed from 2 moles of sucrose in the reaction. The yield of laminaritriose, $22 \mathrm{mM}$, means that $44 \mathrm{~mm}(22 \%)$ of sucrose were consumed to form laminaritriose. If a laminaribiose phosphorylase that does not use laminaribiose as a glucosyl acceptor is obtained, the yield of laminaribiose will be significantly improved.

\section{REFERENCES}

1) V. C. BARRY and J. E. MCCORMICK : Methods Carbohydr. Chem., 1, 328-330 (1962).

2) J. Thiem, A. Sievers and H. Karl : J. Chromatogr., 130, 305-313 (1977).

3) T. G. Villa and H. J. PhafF : Carbohydr. Res., 74, 369-370 (1979).

4) L-X. WANG, N. SAKAIRI and H. KUZUHARA : Carbohydr. Res., 219, 133-148 (1991).

5) M. KITAOKA, T. SASAKI and H. TANIGUCHI : Agric. Biol. Chem., 55, 1431-1432 (1991).

6) M. KITAOKA, T. SASAKI and H. TANIGUCHI : Denpun Kagaku, 39, 281-283 (1992).

7) M. KITAOKA, T. SASAKI and H. TANigUCHI : in Abstracts of 14th Japanese Carbohydrate Symposium, p. 139-140, Tokyo (1992).

8) G. Michael: Methods Enzymatic Anal., 4, 185-191 (1974).

9) J. OKuda, I. Miwa, K. MAedA and K. ToKui : Carbohydr. Res., 58, 267-270 (1977).

10) T. SASAKI, T. TANAKA, S. NAKAGAWA and K. KA INUMA : Biochem. J., 209, 803-807 (1983).

11) S. H. GoldemberG, L. R. MARECHAL and B. C. DESOUzA : J. Biol. Chem., 244, 45-50 (1966).

12) S. KITAO and E. NAKANO : J. Ferment. Bioeng., 73, 179-184 (1992).

(Received September 14, 1992 ; accepted January 29, 1993) 
スクロースホスホリラーゼ，キシロース イソメラーゼ拉よびラミナリビオースホ スホリラーゼを用いたスクロースのラミ

ナリビオースへの変換

北岡本光*，佐々木堯**，谷口 肇

* 日本石油化学株式会社

（100 千代田区内幸町 1-3-1）

** 農林水産省食品総合研究所

（305つくば市観音台 2-1-2）

$* * *$ 岩手県醸造食品試験場

（020 盛岡市津志田 26）

ラミナリビオースを，スクロースを原料として触媒量 のリン酸存在下でスクロースホスホリラーゼ，キシロー スイソメラーゼ拉よびラミナリビオースホスホリラーゼ
を同時に作用させることにより合成した. $50 \mathrm{mM}$ イミ ダゾール-塩酸緩衝液 $(\mathrm{pH}$ 7.0) 中, $20 \mathrm{mM}$ リン酸存在 下に打いて，200 mM スクロースに $0.47 \mathrm{U} / \mathrm{ml}$ スク ロースホスホリラーゼ, $0.072 \mathrm{U} / \mathrm{ml}$ キシロースイソメ ラーゼ, $0.37 \mathrm{U} / \mathrm{ml}$ ラミナリビオースホスホリラーゼの 混合酵素系を $37^{\circ} \mathrm{C}$ で作用させたところ，反応 48 時間後 に反応混液中のラミナリビオース濃度は $110 \mathrm{mM}$ (収率 55\%) 飞達した．反応 15 時間後からラミナリトリオー スの生成がみられ，反応 48 時間後には $22 \mathrm{mM}$ に達し た。また微量のラミナリテトラオースの生成も確認され た. セロビオースホスホリラーゼを用いた同様なセロビ オースの合成実験では，三糖以上のオリゴ糖は生成しな かった．この違いはセロビオースホスホリラーゼが三糖 以上にはまったく作用しないのに対して，ラミナリビ オースホスホリラーゼは弱いながらも三糖以上に作用す るため生成されるものと考察された。 